\title{
Achievement Goals in the Classroom: Students' Learning Strategies and Motivation Processes
}

\author{
Carole Ames and Jennifer Archer \\ University of Illinois at Urbana-Champaign
}

\begin{abstract}
We studied how specific motivational processes are related to the salience of mastery and performance goals in actual classroom settings. One hundred seventy-six students attending a junior high/high school for academically advanced students were randomly selected from one of their classes and responded to a questionnaire on their perceptions of the classroom goal orientation, use of effective learning strategies, task choices, attitudes, and causal attributions. Students who perceived an emphasis on mastery goals in the classroom reported using more effective strategies, preferred challenging tasks, had a more positive attitude toward the class, and had a stronger belief that success follows from one's effort. Students who perceived performance goals as salient tended to focus on their ability, evaluating their ability negatively and attributing failure to lack of ability. The pattern and strength of the findings suggest that the classroom goal orientation may facilitate the maintenance of adaptive motivation patterns when mastery goals are salient and are adopted by students.
\end{abstract}

Recent research on achievement motivation has focused on identifying different types of goal orientations among students, the motivational processes that are associated with these different goals, and the conditions that elicit them. These goal orientations have been contrasted as task involved versus ego involved (Maehr, 1983; Maehr \& Nicholls, 1980; Nicholls, 1979, 1984; see also deCharms, 1968, 1976), as learning oriented versus performance oriented (Dweck, 1986, 1988; Dweck \& Elliott, 1984), and as mastery focused versus ability focused (Ames, 1984a; Ames \& Ames, 1984). Because the conceptual relations among task, learning, and mastery goals and among ego, performance, and ability goals are convergent, these perspectives have been integrated and are hereafter identified as mastery and performance goals, respectively (cf. Ames \& Archer, 1987).

With a performance goal orientation, there is a concern with being judged able, and one shows evidence of ability by being successful, by outperforming others, or by achieving success with little effort. A performance goal reflects a valuing of ability and normatively high outcomes. With a mastery goal, importance is attached to developing new skills. The process of learning itself is valued, and the attainment of mastery is seen as dependent on effort.

Achievement goal orientations are presumed to differ as a function of situational demands, as well as to vary across individuals (Maehr, 1983, 1984). There is, in fact, considerable research evidence that situational demands can affect the salience of specific goals, which results in differential patterns of cognition, affect, and performance (e.g., Ames, 1984b; Ames, Ames, \& Felker, 1977; Covington, 1984; Covington \& Omelich, 1984). For example, when social comparison has been made salient, students have focused on their ability, and these self-perceptions have mediated performance and affec-

This research was supported by a grant from the Research Board of the University of Illinois at Urbana-Champaign.

Correspondence concerning this article should be addressed to Carole Ames, University of Illinois, 51 Gerty Drive, Champaign, Illinois 61820 . tive reactions to success and failure. By contrast, when absolute standards, self-improvement, or participation have been emphasized, students have focused more on their effort and task strategies.

Much of the evidence that has linked different goal orientations with specific motivational processes has amassed from laboratory studies and not from research in ongoing classroom settings (see Dweck, 1988; Nicholls, 1984, for reviews). In classroom situations, the informational cues that may serve to emphasize one goal or another are often mixed and tend to be inconsistent over time. Even students in the same classroom may differ in the degree to which they focus on certain cues, as well as how they interpret them (Brattesani, Weinstein, \& Marshall, 1984; Marshall \& Weinstein, 1984; Ryan \& Grolnick, 1986). These individual differences may result from home influences (Ames \& Archer, 1987; Parsons, Adler, \& Kaczala, 1982), prior experiences (Stipek \& Hoffman, 1980), or differential treatment by teachers (Marshall \& Weinstein, 1986; R. S. Weinstein \& Middlestadt, 1979). Thus the extent to which any student adopts a mastery or performance goal orientation depends on how each student constructs the social reality of the classroom for himself or herself (see Rosenholtz \& Simpson, 1984).

The purpose of this study was to investigate how specific motivation patterns are related to the salience of mastery and performance goals in actual classroom settings. We asked the following questions: Do mastery and performance goal constructs differentiate students' perceptions of their classroom experiences? How are the students' perceptions of the classroom goals related to their task choices, attitudes, and beliefs about the causes of success and failure? Of most importance, we asked how students' perceptions of classroom goals relate to their selection and use of effective learning strategies.

The importance for students of developing ways of thinking and strategies that can help them to process information, plan study activities, monitor their attention, and sustain a motivation for learning has been addressed by many (e.g., Corno \& Mandinach, 1983; Pressley, 1986; Pressley \& Levin, 1983). In this study, we focused on general learning strategies, those 
that can be applied to multiple contexts and that ought to enhance learning across knowledge domains. Learning strategies of this type serve to regulate and monitor time, concentration, effort, and comprehension (McKeachie, Pintrich, \& Lin, 1985) and are related to what others have called support strategies (Dansereau, 1985; Thomas \& Rohwer, 1986), selfinstructions and self-monitoring (Corno \& Mandinach, 1983; C. E. Weinstein \& Mayer, 1986), or strategic thinking (Covington, 1985).

Although there has been considerable research on students' knowledge or awareness of these strategies, there has been little attention as to how the context of learning affects students' actual use of these strategies (cf. McKeachie et al., 1985; Thomas \& Rohwer, 1986). We draw on findings from experimental studies to suggest that students' use of learning strategies may be related to whether students adopt a mastery or performance goal orientation in the classroom. In experimental studies, students have reported using more self-instructions and self-monitoring strategies in conditions rewarding or emphasizing self-improvement rather than social comparison (Ames, 1984b) and when they believed in the efficacy of effort (Bandura \& Schunk, 1981; Diener \& Dweck, 1978; Schunk \& Cox, 1986). Similarly, recent theoretical formulations suggest that students are more likely to think about how to do the task when they are oriented toward learning ( $\mathrm{Ni}$ cholls, 1979, 1984; Nolen, 1987) or focused on their own degree of mastery (Ames, 1984b; Covington \& Omelich, 1984).

Several experimental studies also suggest that students may be more willing to pursue challenging tasks, have positive feelings toward the situation, and exhibit an adaptive attributional pattern when they adopt a mastery orientation (Ames, et al., 1977; Dweck, 1986, 1988; Elliott \& Dweck, 1988; Nicholls, Patashnick, \& Nolen, 1985). Although challenging tasks offer opportunities for learning, they also present the risk of failure, thereby threatening students' sense of worth when failure is normatively defined (Covington, 1984). As a consequence, challenging tasks may be less threatening or more attractive to students who view the situation as emphasizing the process of learning, encouraging effortful activity, and deemphasizing the negative consequences of making errors. In addition, research from diverse perspectives has shown that student satisfaction or enjoyment of learning is greater when classroom environments are perceived as encouraging student involvement (Fry \& Coe, 1980; Trickett \& Moos, 1974) and a sense of personal responsibility (Ryan, 1982; Ryan \& Grolnick, 1986) and when students themselves are committed to understanding and learning (Nicholls et al.,
1985). Last, researchers who have addressed the situational specificity of attributions have consistently found that normative comparisons elicit attributional tendencies that are characteristic of maladaptive motivation patterns (e.g., Ames, 1984a; Ames \& Ames, 1981).

Besides classroom experiences, certain learner characteristics (e.g., self-perceptions of ability) may also be expected to influence how students approach and respond to learning tasks (Bandura, 1982; Covington, 1984; Schunk, 1984). For example, a favorable attitude, a willingness to take risks, and the use of effective learning strategies may be more evident among those students who have normatively high assessments of their ability. Recent evidence (Covington \& Omelich, 1984), however, suggests that a mastery learning paradigm may reduce the impact of perceived ability on achievement behaviors. Nevertheless, how students approach tasks, engage in the process of learning, and respond to the situation may be related to their own perceived ability as well as to the perceived goals of the environment. Thus it seems important to examine the relative contribution of perceived ability and perceived goals to these student variables.

To operationalize mastery and performance goals in the context of the classroom, we first identified the theoretical distinctions between these goals in terms of actual classroom parameters (see Table 1). We then developed a set of questions to assess these characteristics from the students' perspective (see the Method section for further description). Moreover, because we were interested in the relation between each student's perception or interpretation of the situation and individual motivation variables, we used the individual student scores as the unit of analysis rather than the average score of the students at the classroom level. There is now clear evidence that students within the same classroom differ in how they interpret their experiences (e.g., Blumenfeld, Pintrinch, Meece, \& Wessels, 1982; Marshall \& Weinsten, 1984, 1986; Ryan \& Grolnick, 1986). Ryan and Grolnick argued that the concept of a general classroom environment is not sensitive to individual differences in how students give meaning to classroom experiences (p. 556; see also R. S. Weinstein, in press). Thus the likelihood that a student would use effective learning strategies and exhibit an adaptive motivation pattern was expected to be related to how each student perceived the salience of mastery and performance goalsthat is, how each student interpreted his or her own classroom experiences.

In brief, then, we expected students' perceptions of the classroom goals to be related to how they approached, engaged in, and responded to learning tasks. On the basis of theoretical

Table 1

Achievement Goal Analysis of Classroom Climate

\begin{tabular}{lll}
\hline \multicolumn{1}{c}{ Climate dimensions } & \multicolumn{1}{c}{ Mastery goal } & Performance goal \\
Success defined as. .. & Improvement, progress & High grades, high normative performance \\
Value placed on. . & Effort/learning & Normatively high ability \\
Reasons for satisfaction.... & Working hard, challenge & Doing better than others \\
Teacher oriented toward... & How students are learning & How students are performing \\
View of errors/mistakes... & Part of learning & Anxiety eliciting \\
Focus of attention... & Process of learning & Own performance relative to others' \\
Reasons for effort. .. & Learning something new & High grades, performing better than others \\
Evaluation criteria. . & Absolute, progress & Normative \\
\hline
\end{tabular}


formulations and prior research findings, perceived goal orientation was expected to relate to students' learning strategies, task preferences, attitudes, and causal attributions for positive and negative outcomes.

\section{Method}

\section{Subjects and Procedure}

One hundred seventy-six students ( 91 boys and 85 girls) in Grades 8-11 who attended a junior high/high school for academically advanced students participated in the study. These were all students in these grades who were in attendance on the day of testing. In general, admittance to the school requires that students achieve an 80th percentile score on the Secondary School Admission Test (Secondary Admission Test, 1986).

Approximately 4-6 students were randomly selected from each English, math, science, and social studies class offered in the spring semester. Students responded to all questions for the one class from which they were selected. This class was identified at the top of each student's questionnaire (e.g., Biology 1A).

\section{Instruments}

Goal orientation. This set of items was designed to assess students' perceptions of the mastery and performance dimensions of classroom goal structure, as outlined in Table 1. A factor analysis on the total item sample yielded a two-factor solution that confirmed a priori classification of items into Mastery and Performance Goal categories. (Six items were eliminated because they failed to load adequately on either factor.) Coefficient alphas were acceptable for each scale: .88 for the Mastery scale and .77 for the Performance scale. The correlation between the scales was -.03 .

Questionnaire items were prefaced with the heading "In this class ...," and students rated each item on a 5-point Likert scale ranging from strongly disagree (1) to strongly agree (5). Examples of the 19 items constituting the Mastery scale are as follows: "The teacher makes sure I understand the work"; "The teacher pays attention to whether I am improving"; "Students are given a chance to correct mistakes"; "The teacher wants us to try new things"; "Making mistakes is a part of learning"; and "I work hard to learn." Examples of the 15 items from the Performance scale are as follows: "Students want to know how others score on assignments"; "I really don't like to make mistakes"; "Only a few students can get top marks"; "I work hard to get a high grade"; and "Students feel bad when they do not do as well as others."

Learning strategies. Students' reported use of information processing, self-planning, and self-monitoring strategies were assessed with 15 items adapted from the 90-item Learning and Study Strategy Inventory (C. E. Weinstein, Schulte, \& Palmer, 1987). Items were selected to tap strategies that are generic to the process of learning and studying. A factor analysis of the item sample revealed a single factor solution with an alpha coefficient of .84 .

The items on the scale were also prefaced with "In this class ...." and students rated each item on a 5-point scale $(1=$ not at all typical of me; $5=$ very much typical of me). Examples of the items are as follows: "I take time to plan my study schedule for " (subject matter identified); "When studying ___, I try to decide what I am supposed to learn rather than just read over the material"; "I try to pull together the information from class and readings"; "When I study ___ I set goals for myself"; and "I try to relate what I am studying in to other things I know about."
Task challenge. Two questions were used to assess students' preferences for challenging versus easy tasks. On 5-point scales ( $1=$ not likely at all; $5=$ very likely), students were asked to indicate the likelihood of their choosing two types of projects for that class. The items adapted from Elliott and Dweck's (1988; see also Ames \& Archer, 1987) items were (a) "a project where you can learn a lot of new things but will also have some difficulty and make many mistakes" and (b) "a project that would involve a minimum of struggle or confusion and you would probably do very well." The items were conceptually similar, and students' responses to the two items were highly correlated $(r=-.61, p<.001)$. The item scores were therefore combined so that a high score would indicate a preference for challenging work.

Attitude toward class. A single question was used to assess student attitude ("How would you rate your liking for this class?") on a 5point scale $(1=$ very little; $5=a$ lot $)$.

Causal attribution. Students were asked two sets of attribution questions related to when they did well and not very well in class. For each set, students rated the importance of ability (have ability, not have enough ability), effort (worked very hard, not work hard enough), strategy (used good strategies, not use good strategies), the task (work was easy, work was difficult), and the teacher (teacher did a good job, teacher did a poor job) as reasons for their performance. Five-point scales $(1=$ not an important reason; $5=$ an important reason) were used for each rating.

Perceived ability. Students were asked to rate their ability in that subject matter ("How would you rate your ability in this subject compared to other students in your class?") on a 5-point scale (1 = one of the lowest; 5 = one of the highest).

\section{Results}

The hypotheses concerned the relation between each student's perception of the performance and mastery goal orientation of the class and his or her use of learning strategies, attitude, task choices, and causal attributions. In the analyses, therefore, we focused on examining the relation between each student's perception or interpretation of the classroom and the individual student variables. Means and standard deviations for each variable are presented in Table 2 . The first set

Table 2

\section{Descriptive Statistics for Each Variable}

\begin{tabular}{lrr}
\hline \multicolumn{1}{c}{ Measure $^{\mathrm{a}}$} & \multicolumn{1}{c}{$M$} & \multicolumn{1}{c}{$S D$} \\
\hline Mastery structure (19) & 63.12 & 11.58 \\
Performance structure (15) & 52.60 & 7.38 \\
Learning strategies (15) & 45.03 & 10.03 \\
Task challenge (2) & 5.66 & 2.01 \\
Attitude toward class & 3.45 & 1.24 \\
Self-perception of competence & 3.70 & 1.01 \\
Attributions for success & & \\
Ability & 3.74 & 1.11 \\
Effort & 3.88 & 1.13 \\
Strategy & 3.02 & 1.28 \\
Task & 3.21 & 1.15 \\
Luck & 3.38 & 1.24 \\
Attributions for failure & & \\
Ability & 2.51 & 1.16 \\
Effort & 4.07 & 1.07 \\
Strategy & 3.43 & 1.22 \\
Task & 3.64 & 1.12 \\
Luck & 2.74 & 1.40 \\
\hline
\end{tabular}

"Number in parentheses reflects the number of items (when greater than 1) involved in computing the mean. 
Table 3

Zero-Order Correlations Between Perceived Goals and SelfRelated Measures

\begin{tabular}{lcc}
\multicolumn{1}{c}{ Measure } & Mastery & Performance \\
\hline Learning strategies & $.49^{* * *}$ & .12 \\
Attitude toward class & $.63^{* * *}$ & $-.14^{*}$ \\
Task challenge & $.34^{* * *}$ & -.09 \\
Self-competence & $.07^{*}$ & $-.13^{*}$ \\
Causes of success & & -.09 \\
Ability & .11 & $.14^{*}$ \\
Effort & $.37^{* * *}$ & $.24^{* * *}$ \\
Strategy & $.22^{* *}$ & -.06 \\
Task ease & $-.23^{* * *}$ & .01 \\
Teacher & $.47^{* * *}$ & $.21^{* *}$ \\
Causes of failure & & $.00^{*}$ \\
Ability & -.01 & $.16^{*}$ \\
Effort & .11 & $.29^{* * *}$ \\
Strategy & .09 & .12 \\
Task difficulty & -.04 & \\
Teacher & $-.29^{* * *}$ & \\
\hline
\end{tabular}

${ }^{*} p<.05 .^{* *} p<.01 .^{* * *} p<.001$.

of analyses involved zero-order correlations between mastery and performance goals and the other self-report variables. Regression analyses were then used to compare the unique contribution of perceived ability and perceived goal orientation to student's reported use of learning strategies, task choices, and attitude. Last, we made certain profile comparisons across students, asking, for example, whether students who view their class as emphasizing both mastery and performance differ from those students who view their class as high in mastery but low in performance goals.

\section{Correlational Analyses}

Students' scores on mastery and performance scales were correlated with learning strategy, task choice, attitude, and attribution measures. As shown in Table 3, individual differences across these variables were related to the perceived structure of the classroom setting. When students perceived an emphasis on mastery goals, they reported using more learning strategies, preferred tasks that offered challenge, and had a more positive attitude toward their class. This pattern of relation is consistent with theoretical assumptions about the consequences of mastery achievement goals (Dweck, 1988; Nicholls, 1984) and provides field-based evidence of relations that heretofore have been demonstrated in experimental settings (e.g., Ames, 1984b; Bandura \& Dweck, 1981). Students' perceptions of performance goal orientation were not related to their use of learning strategies or task choices, but they were negatively, although not strongly, related to attitudes and self-perceptions of ability.

Causal attributions showed a disparate pattern of relations with the perceived mastery and performance structure. Although effort attributions for success were correlated with both mastery $(r=.37)$ and performance $(r=.14)$ goal orientation, a $T^{2}$ test (Steiger, 1980) for testing differences between nonindependent correlations showed that the perceived covariation between effort and success was more related to the perceived mastery orientation $(p<.05)$. In addition, perceived mastery goal orientation was strongly related to a tendency for students to credit the teacher when they performed well and not blame the teacher when they performed poorly. Positive attitudes and crediting the teacher apparently were not the result of viewing the classwork as easy, insofar as perceived mastery was negatively correlated with attributions to task ease. In contrast, students' perception of the performance, but not mastery, goal emphasis was moderately related to a tendency to attribute failure to lack of ability and to difficult work. Last, mastery and performance both were related to strategy attributions; that is, students tended to believe that "good" study strategies were important to doing well. However, we do not know how students interpreted "good."

\section{Regression Analysis}

Prior research suggested that students' perceived ability is an important predictor of learning strategies, task choices, and attitudes. Therefore, hierarchically ordered regression analyses were used to assess the contribution of perceived goal orientation in relation to the contribution of perceived ability to the aforementioned measures. Self-perception of ability was entered first, followed by the perceived performance goal orientation, then the perceived mastery goal orientation, and the interaction terms. The results are presented in Table 4 . As expected, student's perceived ability was a significant predictor of learning strategies, task choices, and attitudes. However, the perceived mastery orientation remained a highly significant predictor of learning strategies (partial $r=.49$ ), preference for challenge (partial $r=.34$ ), and positive attitudes (partial $r=.63$ ), after ability was entered. Furthermore, the absence of interactions between perceived ability and goal orientation showed that the highly significant effects of mastery goal orientation did not depend on the value or level of perceived ability.

\section{Group Comparisons}

Because mastery and performance were shown to be independent dimensions $(r=-.03)$ of how students perceived the learning environment, it was of additional interest to examine differences among profiles of students. For example, how do students who view their class as having both high mastery and high performance goal orientations differ from those who view their class as having high mastery but low performance?

Table 4

Increments in $R^{2}$ for Hierarchical Regressions on Learning Strategies, Task Choice, and Attitude

\begin{tabular}{lcll}
\hline \multicolumn{1}{c}{ Order of entry } & $\begin{array}{c}\text { Learning } \\
\text { strategies }\end{array}$ & $\begin{array}{c}\text { Task } \\
\text { choice }\end{array}$ & Attitude \\
\hline Perceived ability (A) & $.03^{*}$ & $.07^{* *}$ & $.06^{* *}$ \\
Performance goal (B) & .02 & .00 & .01 \\
Mastery goal (C) & $.23^{* *}$ & $.12^{* *}$ & $.38^{* *}$ \\
A $\times$ B & .00 & .00 & .00 \\
A $\times$ C & .00 & .00 & .00 \\
Total $R^{2}$ & .28 & .19 & .46 \\
\hline
\end{tabular}

${ }^{*} p<.05 .{ }^{* *} p<.001$. 
To make these comparisons, students were divided into four groups on the basis of a median split on each scale. Thus students with above-median scores on both the performance and mastery scales were classified as a high-high (Hi-Hi) group, and remaining students were categorized in low-performance-high-mastery (Lo-Hi), high-performance-lowmastery (Hi-Lo), and low-performance-low-mastery (LoLo) groups (see Table 5). One-way analyses of variance (ANOVAs) and Tukey Honestly Significant Difference (HSD) group comparisons were used to test differences among the four groups on each measure. In Table 5 we present the statistics for these group comparisons.

The ANOVA findings showed significant differences on several measures, and the group comparisons showed a rather consistent pattern of differences on the learning strategy, task choice, and attitude measures. Table 5 shows that the source of the difference was between the highmastery groups (i.e., students' rating the class high on mastery) and the low-mastery groups (students' rating their class low on mastery). There were no differences within the high-mastery groups or within the low-mastery groups. For example, students perceiving the class as high in mastery reported using more learning strategies than did students perceiving the class as low in mastery, regardless of how students perceived the emphasis on performance goals in the classroom. Where significant differences were found, the group comparisons on attributions (particularly effort and teacher attributions) were in this same direction, although the pattern was not as clearly demarcated.

\section{Discussion}

The findings from this study showed that mastery and performance goals provide a meaningful way of differen-

Table 5

Comparisons Among Student Means for Four Groups Split on Performance and Mastery Scores

\begin{tabular}{lccccc}
\hline Variable & Lo-Lo & Hi-Lo & Lo-Hi & Hi-Hi & \\
& $(n=36)$ & $(n=48)$ & $(n=51)$ & $(n=41)$ & $F(3,172)$ \\
\hline Strategies & $39.64_{\mathrm{a}}$ & $41.56_{\mathrm{a}}$ & $47.67_{\mathrm{b}}$ & $50.56_{\mathrm{b}}$ & $12.91^{* *}$ \\
Task challenge & $5.17_{\mathrm{ab}}$ & $4.75_{\mathrm{a}}$ & $6.39_{\mathrm{c}}$ & $6.12_{\mathrm{bc}}$ & $7.11^{* *}$ \\
Attitude & $2.78_{\mathrm{a}}$ & $2.65_{\mathrm{a}}$ & $4.08_{\mathrm{b}}$ & $4.22_{\mathrm{b}}$ & $23.70^{* *}$ \\
Attribution- & & & & & \\
$\quad$ success & & & & & \\
Ability & 3.75 & 3.46 & 3.92 & 3.85 & 1.65 \\
Effort & $3.28_{\mathrm{a}}$ & $3.69_{\mathrm{ab}}$ & $4.03_{\mathrm{bc}}$ & $4.42_{\mathrm{c}}$ & $8.17^{* *}$ \\
Strategy & $2.39_{\mathrm{a}}$ & $3.10_{\mathrm{ab}}$ & $3.00_{\mathrm{ab}}$ & $3.49_{\mathrm{b}}$ & $5.19^{*}$ \\
Task & $3.56_{\mathrm{b}}$ & $3.48_{\mathrm{ab}}$ & $2.90_{\mathrm{a}}$ & $2.98_{\mathrm{ab}}$ & $3.94^{*}$ \\
Teacher & $2.97_{\mathrm{a}}$ & $2.94_{\mathrm{a}}$ & $3.75_{\mathrm{b}}$ & $3.81_{\mathrm{b}}$ & $7.07^{* *}$ \\
Attribution- & & & & & \\
$\quad$ failure & & & & & \\
Ability & 2.11 & 2.88 & 2.47 & 2.49 & 2.56 \\
Effort & 3.97 & 3.94 & 4.16 & 4.22 & 0.93 \\
Strategy & 3.14 & 3.58 & 3.33 & 3.61 & 1.45 \\
Task & 3.31 & 4.02 & 3.49 & 3.68 & 3.39 \\
Teacher & $3.19_{\mathrm{a}}$ & $3.06_{\mathrm{a}}$ & $2.26_{\mathrm{b}}$ & $2.58_{\mathrm{ab}}$ & $4.91^{*}$ \\
\hline Teacher
\end{tabular}

Note. Lo-Lo $=$ low-performance-low-mastery condition; Hi-Lo $=$ high-performance-low-mastery condition; $\mathrm{LO}-\mathrm{Hi}=$ low-performance-high-mastery condition; $\mathrm{Hi}-\mathrm{Hi}=$ high-performance-high-mastery condition. Group means sharing same subscript are not significantly different at the $p<.01$ level.

${ }^{*} p<.01 .{ }^{* *} p<.001$. tiating students' perceptions of the classroom learning environment. Students' perceptions of mastery and performance goals showed different patterns of relation with learning strategies, preference for challenging tasks, attitude toward the class, and beliefs about the causes of success and failure. The consistent pattern of findings across a number of discrete variables suggest that a mastery goal orientation may foster a way of thinking that is necessary to sustain student involvement in learning as well as increase the likelihood that students will pursue tasks that foster increments in learning.

When students perceived their class as emphasizing a mastery goal, they were more likely to report using effective learning strategies, prefer tasks that offer challenge, like their class more, and believe that effort and success covary. These relations were maintained and remained strong when the effects of perceived ability were partialed out. Although self-perceptions of ability may be expected to underlie a motivation or willingness to use learning strategies, our findings suggest that a mastery goal emphasis may provide a context that overrides the contribution of perceived ability to achievement behaviors. Such an interpretation is consistent with other research (Covington, 1984; Covington \& Omelich, 1984) that has shown that the impact of learner characteristics (i.e., self-perceptions of ability) on achievement behavior can be moderated under a mastery learning paradigm. Moreover, the facilitating effects of a mastery-oriented learning environment on these variables were not diminished by the presence of performance cues.

Although a variety of programs for teaching specific study and thinking skills have evolved, our findings suggest that when we ask why students fail to use effective learning strategies, we may not be giving enough attention to the conditions of learning as a factor related to the use of learning strategies. We may need to take stock of how the student perceives the goal orientation of the achievement setting. The degree to which a mastery orientation characterized the classroom learning environment was a critical factor predicting students' use of those strategies that guide and regulate attention and learning activities. This finding is particularly striking for this group of academically advanced students. Although high-achieving students may be expected to be more knowledgeable and aware of effective learning strategies, their reported use of strategies was dependent on how they perceived the goal emphasis of the class.

Whether children opt for challenge in projects that they select for themselves or prefer projects that ensure success has important implications for long-term learning. Similarly, positive attitudes toward a class may very well provide a foundation for a continuing interest in an area. Paralleling the findings on learning strategies, students' task choices and attitudes were distinctly a function of the perceived mastery orientation of the classroom.

The relation between mastery and performance goals in the classroom is particularly noteworthy. The independence of these dimensions allowed us to compare different profiles of student perceptions. These findings showed that it was the degree to which the classroom climate emphasized mastery, rather than performance, that was predictive 
of how students chose to approach tasks and engage in learning. This suggests that the presence of performance cues may not inhibit some aspects of achievement behavior when mastery cues are salient. Jagacinski and Nicholls (1987) also addressed this point. They found that the presence of social comparison information did not reduce students' self-evaluations when they were task involved (i.e., working on projects that they enjoyed).

The attributional pattern associated with mastery and performance goals in the classroom was supportive of prior research in experimental settings. When a performance orientation was salient to students, they tended to focus on their ability, judging their ability to be lower and implicating their ability as a cause of failure. Attributing failure to lack of ability, in addition to the tendency to see the work as too difficult, reflects a maladaptive motivational pattern that is not likely to support subsequent effort. Conversely, perceiving a covariation between effort and success, as students who perceived a mastery-oriented climate did, reflects a more adaptive or success-oriented motivation. Others (e.g., McCombs, 1984) have suggested that perceiving strategies as important to learning is also an important component of achievement-motivated behavior. Although our findings showed that strategy attributions were positively related to both performance and mastery goals, we do not know how students interpreted "used good strategies" as an attributional factor. Inasmuch as others have suggested that strategy attributions should be assessed, it also appears that "strategy" is too broad term and must be defined more specifically for meaningful interpretations to be made.

This study involved a rather homogeneous group of students with respect to achievement level. All students had scored above the national average on standardized achievement tests. Our finding that the motivation patterns of these high-achieving students were responsive to the perceived goal orientation of the classroom is particularly noteworthy. Moreover, even in this restricted range of ability, students' self-perceptions of ability were found to vary considerably and mediate motivated cognitions. In a population with a greater range of actual ability, students' achievement level may also prove to be a significant predictor. Last, we argued that classroom goal orientation is a function of how the individual student interprets and reacts to classroom experiences. Goal orientation, therefore, is determined by what is actually happening in the classroom, but, more important, it is defined by how the individual student gives meaning to these events and what motivational orientation he or she adopts.

\section{Implications}

Although there has been extensive research on classroom climate over the years, much of this research has focused on student achievement as the outcome measure (see Johnson, Maruyama, Johnson, Nelson, \& Skon, 1981, for review). Our findings, however, showed that students' perceptions of classroom climate were related to specific motivational variables that have significant implications for the development of self-regulated learning as well as a long- term involvement and interest in learning (i.e., a masteryoriented achievement pattern).

Prescriptions for changing the goal structure of classroom learning have often focused on decreasing the emphasis that is placed on social and normative comparisons. Our findings, in corroboration with other evidence (e.g., Ames, 1984a; Marshall \& Weinstein, 1984; Rosenholtz \& Simpson, 1984), suggest that such a plan would have the effect of reducing students' tendency to focus on their ability and evaluate their ability negatively. At the same time, how do we get students to engage in adaptive motivation patterns? In other words, how do we get students to focus on effort, use appropriate strategies, make choices that are challenging and engaging, and develop a positive orientation toward learning? Exhorting teachers to decrease the emphasis on social comparison may not ensure that a performance orientation will be supplanted with a mastery orientation. Thus although a reduction in students' tendency to engage in maladaptive thought patterns may be associated with a decreased emphasis on social comparison, it appears that a mastery goal must be salient to students to facilitate an adaptive motivation pattern.

Our findings also suggest that interventions aimed at modifying attributions and training of learning strategies may not have lasting effects if the classroom does not support the targeted outcomes of the intervention. A mastery, but not performance, structure provides a context that is likely to foster long-term use of learning strategies and a belief that success is related to one's effort. Similarly, goalsetting interventions that are aimed at getting students to establish realistic but challenging goals may be further enhanced when a mastery structure is in place.

Modifying or changing the nature of students' experiences in the classroom may provide a viable way of redirecting students' achievement goal orientation. Changing the classroom structure may not help some students who lack certain skills, who are not aware of critical learning strategies, and who, as a result of many accumulated experiences, have adopted a belief that they are not able. Although these students may need to learn new skills, modifying the goal structure of the classroom in such a way that mastery goals are salient and are adopted by students may also be necessary to elicit adaptive motivation patterns.

\section{References}

Ames, C. (1984a). Competitive, cooperative, and individualistic goal structures: A cognitive motivational analysis. In R. Ames \& C. Ames (Eds.), Research on motivation in education: Student motivation (Vol, 1, pp. 177-208). New York: Academic Press.

Ames, C. (1984b). Achievement attributions and self-instructions in competitive and individualistic goal structures. Journal of Educational Psychology, 76, 478-487.

Ames, C., \& Ames, R. (1981). Competitive versus individualistic goal structures: The salience of past performance information for causal attributions and affect. Journal of Educational Psychology, 73, 411-418.

Ames, C., \& Ames, R. (1984). Systems of student and teacher motivation: Toward a qualitative definition. Journal of Educational Psychology, 76, 535-556. 
Ames, C., Ames, R., \& Felker, D. W. (1977). Effects of competitive reward structures and valence of outcome on children's achievement attributions. Journal of Educational Psychology, 69, 1-8.

Ames, C., \& Archer, J. (1987). Mothers' belief about the role of ability and effort in school learning. Journal of Educational Psychology, 18, 409-414.

Bandura, A. (1982). Self-efficacy mechanism in personal agency. American Psychologist, 37, 122-148.

Bandura, M., \& Dweck, C. (1981). Children's theories of intelligence as predictors of achievement goals. Unpublished manuscript, Harvard University.

Bandura, A., \& Schunk, D. H. (1981). Cultivating competence, self-efficacy, and intrinsic interest through proximal self-motivation. Journal of Personality and Social Psychology, 41, 586598.

Blumenfeld, P. C., Pintrinch, P. R., Meece, J., \& Wessels, K. (1982). The formation and role of perceptions of ability in elementary school classrooms. Elementary School Journal, 82, 401-420.

Brattesani, K. A., Weinstein, R. S., \& Marshall, H. H. (1984). Student perceptions of differential teacher treatment as moderators of teacher expectation effects. Journal of Educational Psychology, 76, 236-247.

Corno, L., \& Mandinach, E. (1983). The role of cognitive engagement in classroom learning and motivation. Educational Psychologist, 18, 88-100.

Covington, M. V. (1984). The motive for self-worth. In R. Ames \& C. Ames (Eds.), Research on motivation in education: Student motivation (pp. 77-113). New York: Academic Press.

Covington, M. V. (1985). Strategic thinking and fear of failure. In J. Segal, S. Chipman, \& R. Glaser (Eds.), Thinking and learning skills: Relating instruction to research (pp. 389-416). Hillsdale, NJ: Erlbaum.

Covington, M. V., \& Omelich, C. L. (1984). Task-oriented versus competitive learning structures: Motivational and performance consequences. Journal of Educational Psychology, 76, 10381050.

Dansereau, D. F. (1985). Learning strategy research. In J. Segal, S. Chipman, \& R. Glaser (Eds.), Thinking and learning skills: Relating instruction to basic research (pp. 209-240). Hillsdale, NJ: Erlbaum.

DeCharms, R. (1968). Personal causation. New York: Academic Press.

DeCharms, R. (1976). Enhancing motivation: Change in the classroom. New York: Irvington.

Diener, C. I., \& Dweck, C. S. (1978). An analysis of learned helplessness: Continuous changes in performance, strategy, and achievement cognitions following failure. Journal of Personality and Social Psychology, 36, 451-462.

Dweck, C. S. (1986). Motivational processes affecting learning. American Psychologist, 41, 1040-1048.

Dweck, C. S. (1988). Motivation. In R. Glaser \& Lesgold (Eds.), The handbook of psychology and education (Vol. 1, pp. 187239). Hillsdale, NJ: Erlbaum.

Dweck, C. S., \& Elliott, E. S. (1984). Achievement motivation. In P. Mussen \& E. M. Hetherington (Eds.), Handbook of child psychology (Vol. 4, pp. 643-691). New York: Wiley.

Elliott, E. S., \& Dweck, C. S. (1988). Goals: An approach to motivation and achievement. Journal of Personality and Social Psychology, 54, 5-12.

Fry, P. S., \& Coe, K. J. (1980). Interactions among dimensions of academic motivation and classroom social climate: A study of the perceptions of junior high and high school students. British Journal of Educational Psychology, 50, 33-42.

Jagacinski, C. M., \& Nicholls, J. G. (1987). Competence and affect in task involvement and ego involvement: The impact of social comparison information. Journal of Educational Psychology, $79,107-114$.

Johnson, D. W., Maruyama, G., Johnson, R., Nelson, C., \& Skon, L. (1981). The effects of cooperative, competitive, and individualistic goal structures on achievement: A meta-analysis. Psychological Bulletin, 89, 47-62.

Maehr, M. L. (1983). On doing well in science: Why Johnny no longer excels; why Sarah never did. In S. G. Paris, G. M. Olson, \& H. W. Stevenson (Eds.), Learning and motivation in the classroom (pp. 179-210). Hillsdale, NJ: Erlbaum.

Maehr, M. L. (1984). Meaning and motivation: Toward a theory of personal investment. In R. Ames \& C. Ames (Eds.), Research on motivation in education: Student motivation (Vol. 1, pp. 115-144). New York: Academic Press.

Maehr, M. L., \& Nicholls, J. G. (1980). Culture and achievement motivation: A second look. In N. Warren (Ed.), Studies in crosscultural psychology (Vol. 3, pp. 221-267). New York: Academic Press.

Marshall, H. H., \& Weinstein, R. S. (1984). Classroom factors affecting students' self-evaluations: An interactional model. $R \boldsymbol{e}$ view of Educational Research, 54, 301-326.

Marshall, H. H., \& Weinstein, R. S. (1986). Classroom context of student-perceived differential teacher treatment. Journal of Educational Psychology, 78, 441-453.

McCombs, B. L. (1984). Processes and skills underlying continuing intrinsic motivation to learn: Toward a definition of motivational skills training interventions. Educational Psychologist, $19,199-218$.

McKeachie, W. J., Pintrich, P. R., \& Lin, Y. (1985). Teaching learning strategies. Educational Psychologist, 20, 153-160.

Nicholls, J. G. (1979). Quality and equality in intellectual development. American Psychologist, 34, 107 1-1084.

Nicholls, J. G. (1984). Achievement motivation: Conceptions of ability, subjective experience, task choice, and performance. Psychological Review, 91, 328-346.

Nicholls, J. G., Patashnick, M., \& Nolen, S. B. (1985). Adolescent's theories of education. Journal of Educational Psychology, 77, 683-692.

Nolen, S. B. (1987, April). The influence of task involvement on the use of learning strategies. Paper presented at the annual meeting of the American Educational Research Association, Washington, DC.

Parsons, J. E., Adler, T. F., \& Kaczala, C. M. (1982). Socialization of achievement attitudes and beliefs: Parental influences. Child Development, 53, 310-321.

Pressley, M. (1986). The relevance of the good strategy user model to the teaching of mathematics. Educational Psychologist, 21, 139-161.

Pressley, M., \& Levin, J. R. (1983). Cognitive strategy research: Education foundations. New York: Springer-Verlag.

Rosenholtz, S. J., \& Simpson, C. (1984). The formation of ability conceptions: Developmental trend or social construction? $R e$ view of Educational Research, 54, 31-63.

Ryan, R. M. (1982). Control and information in the intrapersonal sphere: An extension of cognitive evaluation theory. Journal of Personality and Social Psychology, 43, 450-461.

Ryan, R. M., \& Grolnick, W. S. (1986). Origins and pawns in the classroom: Self-report and projective assessments of individual differences in children's perceptions. Journal of Personality and Social Psychology, 50, 550-558.

Schunk, D. H. (1984). Self-efficacy perspective on achievement behavior. Educational Psychologist, 19, 48-58.

Schunk, D. H., \& Cox, P. D. (1986). Strategy training and attributional feedback with learning disabled students. Journal of 
Educational Psychology, 78, 201-209.

Secondary School Admission Test (1986). Princeton, NJ: Educational Testing Service.

Steiger, J. G. (1980). Tests for comparing elements of a correlation matrix. Psychological Bulletin, 87, 245-251.

Stipek, D., \& Hoffman, J. (1980). Children's achievement-related expectancies as a function of academic performance histories and sex. Journal of Educational Psychology, 72, 861-865.

Thomas, J. W., \& Rohwer, W. D. (1986). Academic studying: The role of learning strategies. Educational Psychologist, 21, 19-42.

Trickett, E., \& Moos, R. H. (1974). Personal correlates of contrasting environments: Student satisfaction in high school classrooms. American Journal of Community Psychology, 2(1), 112.

Weinstein, C. E., \& Mayer, R. E. (1986). The teaching of learning strategies. In M. Wittrock (Ed.), The handbook of research on teaching (pp. 315-327). New York: Macmillan.

Weinstein, C. E., Schulte, A. C., \& Palmer, D. R. (1987). Learning and study strategies inventory. Clearwater, FL: H \& H Publishing.

Weinstein, R. S. (in press). Perceived classroom processes and student motivation. In C. Ames \& R. Ames (Eds.), Research on Motivation in Education (Vol. 3). New York: Academic Press.

Weinstein, R. S., \& Middlestadt, S. E. (1979). Student perceptions of teacher interactions with male high and low achievers. Journal of Educational Psychology, 71, 421-431.

Received February 12, 1987

Revision received January 11,1988

Accepted January 28, 1988

\section{Instructions to Authors}

For further information on content, authors should refer to the June 1980 issue of this journal (Vol. 72, No. 3, p. 277). Authors should prepare manuscripts according to the Publication Manual of the American Psychological Association (3rd ed.). All manuscripts must include an abstract of 100-150 words typed on a separate sheet of paper. Typing instructions (all copy must be double-spaced) and instructions on preparing tables, figures, references, metrics, and abstracts appear in the Manual. Also, all manuscripts are subject to editing for sexist language.

APA policy prohibits an author from submitting the same manuscript for concurrent consideration by two or more journals. APA policy also prohibits duplicate publication, that is, publication of a manuscript that has already been published in whole or in substantial part in another journal. Prior and duplicate publication constitutes unethical behavior, and authors have an obligation to consult journal editors if there is any chance or question that the paper might not be suitable for publication in an APA journal. Authors of manuscripts submitted to APA journals are expected to have available their raw data throughout the editorial review process and for at least 5 years after the date of publication. Authors will be required to state in writing that they have complied with APA ethical standards in the treatment of their sample, human or animal, or to describe the details of treatment. (A copy of the APA Ethical Principles may be obtained from the APA Ethics Office, 120017 th Street, N.W., Washington, DC 20036.)

The Journal accepts brief reports of research studies. This category is intended for well-designed studies that replicate or extend previous work but do not merit a large amount of space. Brief reports are published in order of receipt, independent of receipt of regular articles. To ensure that a report does not exceed the maximum three journal pages, follow these instructions: (a) Set the typewriter to a 48 space line and type the text. (b) Count the number of lines, excluding the abstract (75-100 words), title, byline, and acknowledgments, but including references, headings, figures, and tables (the latter should be kept to a minimum). If the number of lines exceeds 250 , shorten the material.

Because the reviewers have agreed to participate in an anonymous reviewing system, authors submitting manuscripts are requested to include with each copy of the manuscript a cover sheet that shows the title of the manuscript, the authors' names and institutional affiliations, the date the manuscript is submitted, and footnotes identifying the authors or their affiliations. The first page of the manuscript should omit the authors' names and affiliations but should include the title of the manuscript and the date it is submitted. Every effort should be made by the authors to see that the manuscript itself contains no clues to their identities.

Authors should submit manuscripts in quadruplicate. All copies should be clear, readable, and on paper of good quality. A dot matrix or unusual typeface is acceptable only if it is clear and legible. Dittoed and mimeographed copies are not acceptable and will not be considered. Authors should keep a copy of the manuscript to guard against loss. Mail manuscripts to the Editor, Robert C. Calfee, School of Education, Stanford University, Stanford, California 94305. 